\title{
Nest-site characteristics and breeding biology of the Black Woodpecker in north-western Lombardy, Italy
}

\author{
Fabio Saporetti*1, Silvio Colaone ${ }^{1}$, Walter Guenzani ${ }^{1}$, Tonino Zarbo ${ }^{1}$
}

\begin{abstract}
Riassunto - Caratteristiche del sito riproduttivo del Picchio nero nella Lombardia nord-occidentale, Italia.

Nel periodo 2008-2012 abbiamo studiato le caratteristiche del sito riproduttivo del Picchio nero Dryocopus martius in 3 aree di studio in provincia di Varese (Lombardia nord-occidentale). La specie, di recente insediamento nella provincia e nelle adiacenti fasce prealpine, seleziona piante-nido con diametro di grandi dimensioni, prevalentemente latifoglie, specie alloctone incluse; l'intorno $(0,12 \mathrm{ha})$ della pianta nido presenta una minore densità di fusti con diametro medio più elevato rispetto ai cerchi random ubicati nel raggio di 500 metri dalla pianta nido. Abbiamo seguito 21 nidificazioni in 10 territori: 18 di queste hanno portato all'involo di 42 giovani, con un tasso d'involo pari a 2,33 juv - coppia, mentre 3 nidificazioni hanno avuto esito negativo. Il Picchio nero può essere considerato come uno specialista nella scelta del sito di nidificazione e generalista a livello di home-range, come dimostrano alcuni territori adiacenti a trafficate strade asfaltate ed aree urbanizzate. L'espansione della specie, dalla zona montana, prosegue verso le aree collinari centrali e nell'alta pianura occidentale, lungo il corridoio ecologico forestale adiacente al Lago Maggiore e al fiume Ticino.
\end{abstract}

Parole chiave: Picchio nero, sito riproduttivo, successo riproduttivo, espansione dell'areale.

\begin{abstract}
In the years 2008-2012 we studied the nest-site characteristics of the Black Woodpeckers Dryocopus martius in the Varese province, in 3 study-areas in north-western Lombardy. The Black Woodpecker is a recent immigrant in our study area and in the surrounding pre-Alps; it selects wide-diameter trunk of mainly broadleaf trees, and the forest structure near the nest is significantly different from that of random spots within $500 \mathrm{~m}$ from the nest, with less dense trees of greater Diameter at Breast Height. We monitored 21 nesting events, of which 18 were successful and fledged 42 young, while 3 were unsuccessful; the overall fledging rate is 2,33 young/pair. The Black Woodpecker may be considered a habitat specialist for the nest site and habitat generalist in the home-range, with some territories very close to busy paved road and urbanized areas. From the origi-
\end{abstract}

${ }^{1}$ Gruppo Insubrico di Ornitologia Onlus, Civico Museo Insubrico di Storia naturale di Clivio e Induno Olona, Via Manzoni 21, 21050 Clivio (VA), Italia

* Corresponding author: saporettif@gmail.com

(C) 2016 Fabio Saporetti, Silvio Colaone, Walter Guenzani, Tonino Zarbo

Received: 28 January 2015

Accepted for publication: 25 September 2015 nal mountain sector, the Black Woodpecker expanded its range to the lower hill and, and, further south towards the plain, through the ecological corridor of the forests adjoining Lake Maggiore and the Ticino river.

Key words: Black Woodpecker, nest site, reproductive success, range expansion.

\section{INTRODUCTION}

The Black Woodpecker in Europe is considered the best studied species among Picidae (Pasinelli, 2006), at least in term of population biology (Cuisin, 1968; Rudat et al., 1981; Lang \& Rost, 1990; Lange 1996, Meyer \& Meyer, 2004, Kunzmann et al., 2008), habitat and nest selection (Blume 1996, Rolstad et al., 1998; Rolstad et al., 2000; Bocca et al., 2007, Brambilla \& Saporetti, 2014). Most publications refer to central and northern Europe (Pasinelli, 2007), while for Italy a large gap in knowledge exists about range, population size and demographic parameters, and no data are available on breeding success (Brichetti \& Fracasso, 2007). The population of the species was estimated at 1300-3700 pairs for whole Italy (Brichetti \& Fracasso, 2007): the breeding range is limited to the Alps and to mountain forests in central and southern Apennines, which holds a very tiny population (100-150 pairs; Gustin et al., 2009); in the northern Appennines only a few pairs breed in the Foreste Casentinesi Monte Falterona e Campigna National Park (Ceccarelli et al., 2008). Along the Alps of northern Italy the distribution range is more continuous, from west to east, and in the last decade the species has undergone a marked range expansion, into the pre-Alpine, hill, and even reached the sea level in Friuli Venezia Giulia (Utmar \& Padovan, 2005). The range expansion was particularly noteworthy in Piedmont (Aimassi \& Reteuna, 2007) and Lombardy (Saporetti \& Pianezza, 2010). In the latter region, up to the eighties, the species was distributed only on the coniferous and mixed forests of the central and eastern mountain area, between 1000 and 1700 m a.s.l. (Brichetti \& Fasola, 1990), whereas in the last decade it extended his breeding range in the western sector of Varese and Como's Province (Saporetti \& Pianezza, 2010; Bonvicini, pers.comm.; Brambilla, pers. comm.). In the central part of this region the range expansion is evident in Bergamo Province, where the species now is spreading in a wide belt of the pre-alpine 
mountains (Cairo and Facoetti, pers.comm. and preliminary results of the ongoing atlas of breeding birds). In the Province of Varese the Black Woodpecker has been a winter visitor for a long time (Bianchi et al., 1973) and did not breed from 1983 to 1987 (Guenzani \& Saporetti, 1988; Brichetti \& Fasola, 1990). The reproduction of the very first pair was documented only in 1993 (Parnell et al., 1994); from 2003-2005 its expansion was evident in the northern mountain sector (Gagliardi et al., 2007). In 2006 the Black Woodpecker nested for the first time at $310 \mathrm{~m}$ a.s.l in the Regional Park of the Pineta of Appiano Gentile and Tradate (Varese and Como Provinces) where it had been up to then an uncommon winter visitor. With our work, we tried to assess the breeding biology, habitat selection, nest site and the timing of the reproduction of the Black Woodpecker in the pre-Alps, in order to understand the main environmental parameters affecting the choice of the forest patch.

\section{MATERIALS AND METHODS}

\section{Study area}

The study was conducted from 2008 to 2012 in northwestern Lombardy, northern Italy, in the Province of Varese and, marginally, in the province of Como. We have selected three main study areas (Fig. 1), each one characterized by different landscape structure, vegetation cover and amount of urbanization:

A - Pineta of Appiano Gentile and Tradate Regional Park (coniferous, mixed and deciduous forests)

B - Site of Community Importance IT 2010016 Val Veddasca (mountain forest, mainly deciduous with low urbanization)

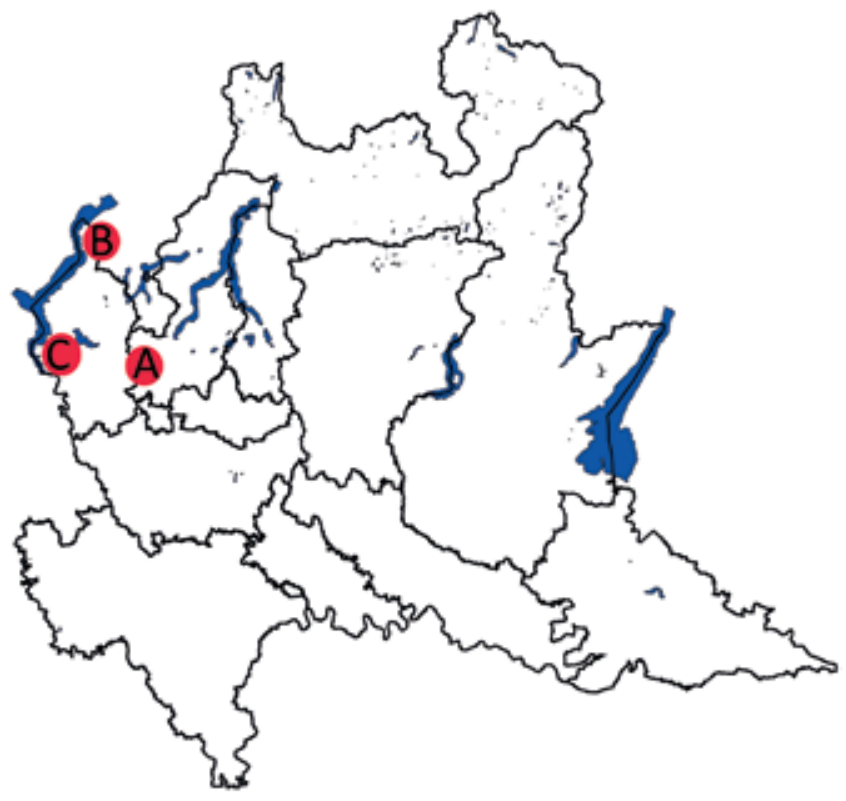

Fig. 1 - Nest area of first territory (n. 1, A area and Tab. 3) found in the Parco Pineta of Appiano Gentile and Tradate: the nest trees are the two spruce on the right (pointed with red arrows), felled after forestry sanitation operations. Photo by Silvio Colaone.
C - A central sector, close to the western side of Lake Maggiore and Varese, (fragmented woodland, mainly deciduous, arable land, meadows with patchy urbanization)

\section{Survey of breeding pairs}

For each areas, from the end of February until the first half of April, we intensively searched for active territorial pairs (courtship with drumming and calling, mating, intraspecific fights) in mature stands of coniferous, mixed or deciduous forest: for any territorial pairs we tried to locate the cavities already available for nesting or the start of a new excavation. We never used play-back to stimulate the responses of the individuals. For each territorial pairs associated to a nest-hole, hereafter probably nesting, we checked for egg laying (entrance in the nest cavity and resting for incubation of female or male); then we checked for subsequent food delivery to finally asses the fledging rate.

\section{Habitat variables}

The forest stand parameters were measured for the nest tree, the nest site, and at home-range scale in five 0.12 ha circles $(\mathrm{r}=20 \mathrm{~m})$, the central one centered in the nest tree and the other 4 randomly spaced within a radius of $500 \mathrm{~m}$ from the nest tree. In the 0,12 circles we recorded: number of trees and species, tree health (dead, partially rotted or alive), DBH $>8 \mathrm{~cm}$ in 9 classes (Diameter at Breast Height, Tab. 1), the vegetation type according to the Vegetation Map; from these data we obtained the number of trees/ha. We counted the number of logs (laying dead trunk) and the number of snags (standing dead trees with broken top). For every occupied territory we measured the forest stand parameters as soon as possible, at the end of the breeding period, in the first year of the discovery. For the landscape scale, within a radius of 1500 $\mathrm{m}$ from the nest tree, we derived a set of 5 land cover variables (Tab. 2) with ArcView 9.0, utilizing the Vegetation Map of the Province (Tosi \& Zilio, 2002), based on the 1:10.000 Regional Technical Map of Lombardy Region, in 3 buffer area of radius of $500 \mathrm{~m}$ (78.5 ha), the first one centered on the nest tree and two other random. We used non-parametric statistical tests.

Tab. 1 - Diameter at Breast Height (DBH) classes (cm).

\begin{tabular}{|c|c|}
\hline 1 & $8.0<\mathrm{DBH}<15.0$ \\
\hline 2 & $15.0<\mathrm{DBH}<23.0$ \\
\hline 3 & $23.0<\mathrm{DBH}<36.0$ \\
\hline 4 & $36.0<\mathrm{DBH}<53.0$ \\
\hline 5 & $53.0<\mathrm{DBH}<69.0$ \\
\hline 6 & $69.0<\mathrm{DBH}<84.0$ \\
\hline 7 & $84.0<\mathrm{DBH}<102.0$ \\
\hline 8 & $102.0<\mathrm{DBH}<121.0$ \\
\hline 9 & $\mathrm{DBH}>121$ \\
\hline
\end{tabular}


Tab. 2 - Set of 5 land cover variables within a radius of $1500 \mathrm{~m}$ from the nest tree. Total forest cover is the sum of broadleaf and coniferous forest; total "open" habitat: this category includes all the herbaceous categories of the vegetation map, and cropland.

\begin{tabular}{|c|}
\hline derived land cover variables (ha) \\
\hline total forest cover \\
\hline total broadleaf cover \\
\hline total coniferous forest \\
\hline total "open" habitat \\
\hline total urban area \\
\hline
\end{tabular}

\section{RESULTS}

\section{Breeding biology}

Overall we monitored 21 nesting events in 10 different territories: 6 in area A, 5 in area B and the remaining 10 in area $C$, with 18 successful broods and 3 unsuccessful ones; in two territories ( 1 and 5) the breeding pairs were already known since 2006. Tab. 3 reports the numbers of years in which each of the 10 territories was occupied by a nesting pair (range 1-5 years, only for territory n. 1, we considered also the 2007 datum, Fig. 2 ), the number of successful broods (range 1-4) and the

Tab. 3 - Number of territories of each area, number of years in which each territory was occupied, number of successful broods and total number of fledged juveniles for each territory.

\begin{tabular}{|c|c|c|c|c|}
\hline Territory number and area & Years & Number of successful broods & Fledged young & Number of unsuccessful broods \\
\hline $1(\mathrm{~A})$ & 5 & 4 & 10 & 1 \\
\hline $2(\mathrm{~A})$ & 1 & 0 & 0 & 1 \\
\hline $3(\mathrm{~B})$ & 3 & 3 & 8 & 0 \\
\hline $4(\mathrm{~B})$ & 2 & 2 & 4 & 0 \\
\hline $5(\mathrm{C})$ & 1 & 1 & 3 & 0 \\
\hline $6(\mathrm{C})$ & 2 & 2 & 4 & 1 \\
\hline $7(\mathrm{C})$ & 2 & 1 & 2 & 0 \\
\hline $8(\mathrm{C})$ & 2 & 2 & 4 & 0 \\
\hline $9(\mathrm{C})$ & 1 & 1 & 2 & 0 \\
\hline $10(\mathrm{C})$ & 2 & 2 & 5 & \\
\hline & 18 & 42 & 3 & \\
\hline
\end{tabular}

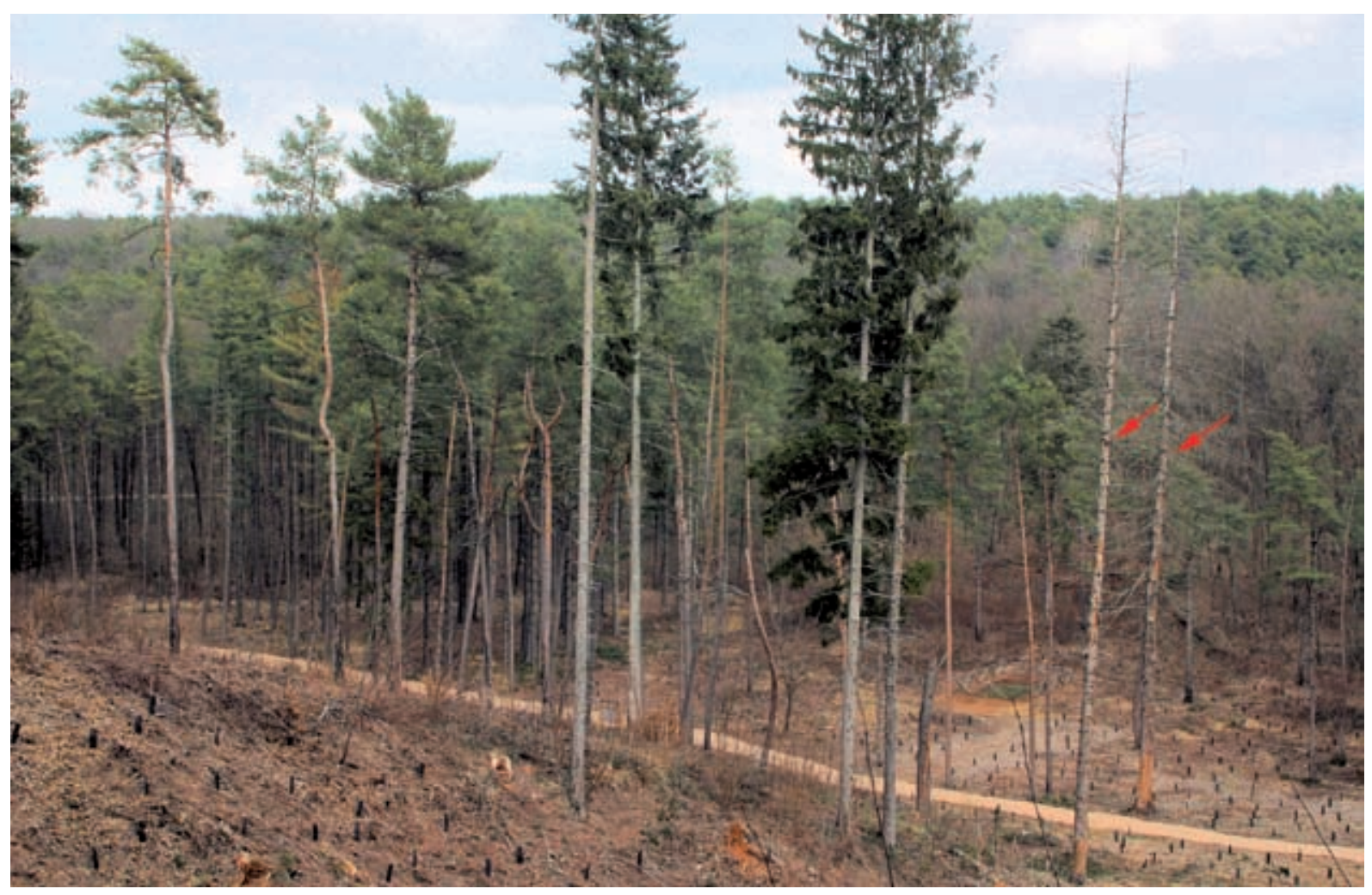

Fig. 2 - Nest area of first territory (n.1, A area and Tab. 3) found in the Pineta of Appiano Gentile e Tradate Park: the nest trees are the two spruce on the right (pointed with red arrows), felled after forestry sanitation operations. Photo by Silvio Colaone. 
total number of young fledged (range 2-10) for each territory. The mean number of nesting events monitored each year was 3,6 (d.s. $=1.52)$, with a minimum in 2008 ( 2 pairs) and a maximum in 2011 (6 pairs). The fledging rate was equal to 2.33 juveniles/pairs and the median fledging rate did not differ among 5 years (KruskasWallis $\mathrm{H}$ test $=2.222 ; \mathrm{P}=0.549$ ).

The fledging period ranged from the third decade of May (earliest date 21 may 2012, area A and C) to the second decade of June for the area $B$, with a peak in the third decade of June (mountain area B, above $900 \mathrm{~m}$; latest date 25 June 2012), generally two weeks later than those of area A and C. Assuming an incubation period of 12-14 days (Blume, 1996; Cramp, 1985) and a fledging period of 24-28 days (Cramp, 1985), the start of the laying may be dated approximately between the first and the second decade of April (11-15 $\left.{ }^{\text {th }}\right)$ for the areas A and $\mathrm{C}$ and between the last decade of April and the first decade of May for area B (from $30^{\text {th }}$ of April till $6^{\text {th }}$ of May). The first unsuccessful brood (territory n.2, area A) was found in 2009: the nest was deserted about ten days after the start of the incubation and both members of the pair abandoned the nest-site for unknown reasons; the others two were respectively territory number 1 in year 2010 and territory number 8 in year 2012 and both the nests were deserted with the young inside, when their growth rate was already in the third week of development. We do not know the reason of nest-desertion because both nest sites were not disturbed by people or forestry operation. In the territory number 1 (year 2012) we observed a Carrion Crown Corvus cornix trying to predate the two young at the hole entrance: subsequently we found the remains of one young at the tree base; in one mountain territory (n.3, year 2010) one young was predated by a Fox Vulpes vulpes soon after fledging
(Rinetti, pers. comm.). The sex ratio (male:female) of 27 sexed fledged young is 1.08:1 (14 males, 13 females). The extent of red color on the crown of the young woodpeckers is useful to determine the sex: for females is a little patch on the hindcrown while in males there is a stripe starting above the upper mandible and arriving to the hindcrown.

\section{Selection of the nest tree}

Among the 15 trees where we found nest holes with breeding pairs, 12 were excavated in deciduous tree $(80.0 \%)$ and 3 in coniferous one $(20.0 \%$; only in area A), and the great majority were alive (12 or $80.0 \%)$. Only in two territories (n.1/ 2007/2011/2012 and n.5/2008) the trees were dead (respectively Picea excelsa and Populus $a l b a$ ) or partially decayed (n.1/2010, Pinus strobus). The Beech Fagus sylvatica was the most commonly selected deciduous trees $(\mathrm{n}=5$; area $\mathrm{B}$ and $\mathrm{C})$ above $500 \mathrm{~m}$, while other 4 species were selected in area $C$ (Tab. 4). The mean Diameter at Breast Height (DBH) is $59,5 \mathrm{~cm}$ $(n=15$, d.s. \pm 20.96$)$, whereas the nest height averaged 11.9 $m(n=16$, d.s. $\pm 2.86 ;$ Tab. 4). The mean height of the nest holes in deciduous trees is $11.0 \mathrm{~m}(\mathrm{~d} . \mathrm{s.} \pm 2.56 ; \mathrm{n}=12)$, in coniferous trees is $14.5 \mathrm{~m}(\mathrm{~d} . \mathrm{s} . \pm 2.25$; $\mathrm{n}=4)$; Mann-Whitney $\mathrm{U}$ test $=40.0, \mathrm{P}=0.0582$, two-tailed. In one territory (number 3, 2009/10/11) the same nest hole was reused for 3 consecutive years, whereas in other five (n.1 2011/12, n. 4 2011/12, n.7 2010/11, n.8 2010/11 and n.10 2011/12) for two consecutive years. In two territories (n.1 and n.4, 2011) we were able to monitor the number of days used by the pairs for the excavation of the nest-hole. For the first pair, at an altitude of $975 \mathrm{~m}$, we found excavating male and female on $9^{\text {th }}$ April, at about one week since the start of the cavity, because both members were again excavating on the external side of the hole, with only head

Tab. 4 - Number of territories, nest trees (dead or partially decayed and alive) for each territory, Diameter at Breast Height (DBH), tree species, number of nest holes, nest height and altitude of the nest trees. $\left.{ }^{a}\right)$ In the territory n. 1 the nesting pair used the same dead tree (Picea abies) in 2007 and 2011/12, excavating a different hole in 2011, reused in 2012. ${ }^{b}$ ) In the territory n. 3 the nesting pairs used the same nest hole for three consecutive year.

\begin{tabular}{|c|c|c|c|c|c|c|c|c|}
\hline $\begin{array}{c}\text { Territory } \\
\text { number }\end{array}$ & $\begin{array}{c}\text { Nest } \\
\text { trees }\end{array}$ & $\begin{array}{c}\text { Dead or } \\
\text { partially } \\
\text { rotted }\end{array}$ & Alive & DBH (cm) & Tree species & $\begin{array}{c}\text { Nest } \\
\text { holes }\end{array}$ & Nest height (m) & $\begin{array}{c}\text { Altitude (m } \\
\text { a.s.l.) }\end{array}$ \\
\hline 1 & 3 & 2 & 1 & $45,49,73$ & $\begin{array}{c}\text { Picea abies, } \\
\text { Pinus strobus }\end{array}$ & $4^{\text {a }}$ & $12.3-13.2-15-17.4$ & $305-310-320$ \\
\hline 2 & 1 & & 1 & 34 & Robinia pseudoacacia & 1 & 13.2 & 360 \\
\hline 3 & 1 & & 1 & 105 & Fagus sylvatica & $1^{\mathrm{b}}$ & 8.5 & 1165 \\
\hline 4 & 1 & & 1 & 96 & Fagus sylvatica & 1 & 12.6 & 975 \\
\hline 5 & 1 & 1 & & 76 & Popolus alba & 1 & 8 & 258 \\
\hline 6 & 2 & & 2 & 39,48 & Quercus rubra & 2 & $15-15.1$ & 290 \\
\hline 7 & 2 & & 2 & 46,52 & Fagus sylvatica, & 2 & $10-10$ & $720-699$ \\
\hline 8 & 2 & & 2 & 59,75 & Fagus sylvatica & 2 & $8.3-11$ & $555-565$ \\
\hline 9 & 1 & & 1 & 49 & Popolus alba & 1 & 8.5 & 245 \\
\hline 10 & 1 & & 1 & 46 & Popolus alba & 1 & 12 & 250 \\
\hline
\end{tabular}


and neck penetrating the cavity, which was terminated in the first days of May: in this case we presumed an excavating lengths of 35 days at least; for the second one (altitude $320 \mathrm{~m}$ ) the very start date began the $1^{\text {th }}$ March and termed the $8^{\text {th }}$ April, for a total of 39 days. All the nest holes in deciduous tree were excavated below the lowest branch. The spacing of successive nest tree, from year to the subsequent one in the same nesting territory in 4 nest-site (n.1, n.6, n.7, n.8) has a mean value of $76.0 \mathrm{~m}$ (d.s. \pm 67.38 ), with a minimum of $18 \mathrm{~m}$ and a maximum of $203 \mathrm{~m}(\mathrm{n}=6)$. In the Pineta of Appiano Gentile and Tradate Regional Park (territory n. 1) two nest tree were felled (in 2008 and 2010) during forestry sanitation operations, partly connected to the control of on outbreak of Ips typographus (family Scolitidae).

\section{Nest site and landscape scale}

The difference between DBH of the 15 nest trees and the mean DBH of the trees in the 0,12 circle (nest centered) is highly significant (Mann-Whitney $U$ test $=9.0$, $\mathrm{P}=0.0022$, two-tailed test) as significant is the number of trees/ha with random circles too (Mann-Whitney $\mathrm{U}$ test $=80.0, \mathrm{P}=0.021$, two-tailed test): only in two territories (n. 2 and n. 10) the birds selected a higher tree density in the nest circle than in random ones. The value of mean nest tree diameter belongs to the $5^{\text {th }} \mathrm{DBH}$ class that, in the random 0,12 circles, collects only $1.34 \%$ of all the measured trunks $(n=4168)$. In the nest circle, the number of dead trunks (log or snag) is remarkably lower than random circles (Sign test $r=13, P=0.000244$ ). The nest site were located mainly $(83.3 \%)$ in deciduous forest, with only two in coniferous ones $(16,7 \%$, in area A): the species composition of the forest stand in the 0.12 ha nest circle versus the random circles (mean values) is similar but with different percentages (Tab. 5) among tree species, particularly for Fagus sylvatica that is one of the preferred nest tree species above $500 \mathrm{~m}$ a.s.l. It is worth noting the high percentage represented for some invasive alien species as Robinia pseudacacia, Quercus rubra and Prunus serotina; the species composition indicates also a high percentage value of Alnus glutinosa stand (Tab. 5), corresponding to the alluvial forest, where the species frequently forages. In only one territory (n. 5,2008$)$ the nest tree (a dead one) was located in a small clump of 10 trunks isolated in a meadows, $200 \mathrm{~m}$ far away from the woodland edge: in winter of the same year the trunk fell down. Two nest trees were located in private park and 5 were excavated in large trees on the pathways border, often used for recreation walking and forest felling operations.

The mean distance of the nest trees from the nearest pathway was $26 \mathrm{~m}$ (d.s. \pm 35.5 ; $\min =1 \mathrm{~m}$; $\max =112$ $\mathrm{m})$ : the parameter "distance from the nearest pathway" is strongly preferred (Mann-Whitney $\mathrm{U}$ test $=119.5$, $\mathrm{P}=0.0067$, two-tailed test), as the distance from the nearest clearing (Mann-Whitney $\mathrm{U}$ test $=115, \mathrm{P}=0.0143$, twotailed test).

The six forest stand parameters are statistically significant (Tab. 6), with the number of trees/hectare and distance from the nearest pathway highly significant; three of the five derived variables (total forest cover, total co- niferous forest cover and total open habitat) do not vary significantly among nest and random circles, whereas total broadleaf cover and total urban area are statistically significant.

Tab. 5 - Tree species composition in the 0.12 ha nest and random circles (mean value among 4 circles). * Other 11 tree species with percentage $<1 \%$ to reach $100 \% ; * *$ other 22 tree species with percentage $<1 \%$ to reach $100 \%$.

\begin{tabular}{|c|l|r|c|}
\hline N. & \multicolumn{1}{|c|}{ Tree species } & $\begin{array}{c}\text { \% nest } \\
\text { circle }\end{array}$ & $\begin{array}{c}\text { \% random } \\
\text { circles }\end{array}$ \\
\hline 1 & Fagus sylvatica & 25.4 & 12.8 \\
\hline 2 & Robinia pseudacacia & 11.8 & 12.9 \\
\hline 3 & Castanea sativa & 11 & 15.6 \\
\hline 4 & Quercus rubra & 10.2 & 2.8 \\
\hline 5 & Platanus orientalis & 6.6 & 2.2 \\
\hline 6 & Fraxinus excelsior & 6.4 & 4.9 \\
\hline 7 & Pinus sylvestris & 5.5 & 8.8 \\
\hline 8 & Prunus serotina & 4 & 1.3 \\
\hline 9 & Popolus alba & 2.9 & 0.2 \\
\hline 10 & Alnus glutinosa & 2.4 & 10.7 \\
\hline 11 & Quercus robur & 2.2 & 3.2 \\
\hline 12 & Ostrya carpinifolia & 2.1 & 0.5 \\
\hline 13 & Carpinus betulus & 1.7 & 1.1 \\
\hline 14 & Tilia cordata & 1.6 & 0.2 \\
\hline 15 & Betula pendula & 1.1 & 8.4 \\
\hline 16 & Acer pseudoplatanus & 1.1 & 1.9 \\
\hline & \% total & $98.1 *$ & $88.7 * *$ \\
\hline
\end{tabular}

\section{DISCUSSION}

The mean brood size of 2.33 young per successful breeding is a low value if compared with values available for central Europe (Tab. 7). We can hypothesize three main causes to explain such figure: A) the small sample of nesting events monitored, B) a low level of food resources in our sub-optimal study area, at the base of the main distribution belt of the Alps, where the colonization process is still in progress, and where the species maintains its population stronghold in the optimal habitat with mixed and coniferous forests, C) an unbalanced age-classes population structure with a high number of 1 -yr old females, factor that is quoted (Rolstad et al., 2000) as a cause of high desertion rate. In our sample the $14.3 \%$ of the brood were deserted, one during the incubation period (territory n. 2 , in Robinia pseudacacia) and two (territory n. 1 and n. 8) in the growing period: for the first one we can hypothesize the very small DBH of the selected trunk, then of the nesting chamber, to act as cue for abandonment; for the others, in particular for territory n. 1, we can't exclude the predation of a member of the pairs. 
Tab. 6 - Results of the Mann-Whitney U test for the 5 derived cover variables and the 6 forest stand parameters. n.s., not significant; $* \mathrm{P}<0.05$; $* * \mathrm{P}=<0.01$; nest and random buffer $(\mathrm{r}=500 \mathrm{~m})$ cover for the nest circle and random circles (mean value).

\begin{tabular}{|c|c|c|c|c|}
\hline & $\begin{array}{l}\text { Nest buffer } \\
\text { cover }\end{array}$ & $\begin{array}{c}\text { Random buffer } \\
\text { cover }\end{array}$ & $\begin{array}{c}\text { Mann-Whitney } \\
\text { U test }\end{array}$ & Significance \\
\hline \multicolumn{5}{|c|}{ Derived variables } \\
\hline Total forest cover (ha) & 60.21 & 45.73 & $\mathrm{U}=52, \mathrm{P}=0.2585$ & n.s. \\
\hline Total broadleaf cover (ha) & 44.08 & 23.07 & $\mathrm{U}=36, \mathrm{P}=0.0404$ & $*$ \\
\hline Total coniferous cover (ha) & 15.23 & 5.43 & $\mathrm{U}=65, \mathrm{P}=0.7039$ & n.s. \\
\hline Total "open” habitat (ha) & 12.48 & 15.36 & $\mathrm{U}=75, \mathrm{P}=0.8887$ & n.s. \\
\hline Total urban area (ha) & 3.76 & 12.80 & $\mathrm{U}=107, \mathrm{P}=0.0466$ & $*$ \\
\hline \multicolumn{5}{|c|}{ Measured variables } \\
\hline Tree numbers/ha & 391.30 & 716.40 & $\mathrm{U}=128, \mathrm{P}=0.0014$ & $* *$ \\
\hline Numbers of trees in 1-4 DBH classes & 48.08 & 137.90 & $\mathrm{U}=117,5, \mathrm{P}=0.093$ & $*$ \\
\hline Numbers of trees in 5-9 DBH classes & 3.75 & 1.50 & $\mathrm{U}=35,5, \mathrm{P}=0.0375$ & $*$ \\
\hline Number of dead plants (snag/log) & 3.75 & 13.58 & $\mathrm{U}=114,5, \mathrm{P}=0.0155$ & $*$ \\
\hline Distance from the nearest pathway & $26 \mathrm{~m}$ & $94.71 \mathrm{~m}$ & $\mathrm{U}=119,5, \mathrm{P}=0.0067$ & $* *$ \\
\hline Distance from the nearest clearing & $55.75 \mathrm{~m}$ & $205.70 \mathrm{~m}$ & $\mathrm{U}=115, \mathrm{P}=0.0143$ & $*$ \\
\hline
\end{tabular}

Tab. 7 - Breeding success among our study and central European data.

\begin{tabular}{|l|c|c|}
\hline Author & $\begin{array}{c}\text { Breeding } \\
\text { success }\end{array}$ & $\begin{array}{c}\text { Number of } \\
\text { nesting events }\end{array}$ \\
\hline This study & 2.33 & 18 \\
\hline Rudat et al. 1981 & 2.83 & 70 \\
\hline Meyer \& Meyer 2004 & 2.88 & 476 \\
\hline Lange 1996 & 3.04 & 140 \\
\hline Lang \& Rost 1990 & 3.11 & 134 \\
\hline Cuisin 1981 & 3.17 & 23 \\
\hline Tjernberg 1993 & 3.70 & 35 \\
\hline
\end{tabular}

We consider this species quite tolerant of anthropogenic disturbance as should be a taxon in the colonization process of our study area: some of the pairs we monitored had a nest we could define in prominent position, very close to well-known pathways; if we take into account the loudness of theirs vocalizations in the pre-laying period, which greatly increase the conspicuousness of the species, this view is furthermore supported. From our results the Black Woodpeckers may be considered a species halfway between a habitat specialist and habitat generalist, if we examine the territory preferences at different scales: specialist at nest scale and generalist at landscape scale for habitat selection. The nest tree, with his considerable diameter at breast height is statistically different from the available trees in the home-range, as well the tree number/ ha in the nest circle, because the species requires a significant spacing of the trees in the immediate proximity of the nest, as confirmed also by close proximity to the nea- rest pathway and to the nearest clearings. The nest found in area A (territory number 2) excavated in the smallest trunk $(\mathrm{DBH}=34 \mathrm{~cm})$ among those selected by the monitored pairs, led to the desertion of the brood: generally the average DBH necessary to hold the nesting cavity is around $40 \mathrm{~cm}$ (Kosinski et al., 2007; Gorman, 2011) and in literature the mean values range from $40 \mathrm{~cm}$ to $56.5 \mathrm{~cm}$ (Tab. 7). Our mean value $(59.5 \mathrm{~cm})$ is clearly very high if confronted with the cited literature. It should be noted that very low diameters are also know: Falcone (2007) reports a minimum value of $22 \mathrm{~cm}$ for the natural Park of Mont Avic, whereas Pynnönen (1939) cites an example of 27 $\mathrm{cm}$. Rolstad et al. (2000) provides different measures for different trees, with the modal class corresponding to a diameter of $35 \mathrm{~cm}$ for the dead trees without bark, $45 \mathrm{~cm}$ for Pinus sylvestris and $45 \mathrm{~cm}$ for Populus tremula. The mean nest heights in our study area are also in the upper level, with respect of other studies (Tab. 7), and our lowest value $(8 \mathrm{~m})$ is higher than the mean value found by Colpi et al. (2009) and Ceccarelli et al. (2008) in beech-wood of respectively the Dolomiti Bellunesi National Park and Foreste Casentinesi National Park: if we consider only the mean height of holes (10.8 m, Tab. 4) in broadleaf forest, the difference with the Italian data (Tab. 8) remains substantially unaltered, indicating the selection of available old deciduous trees in the forest patch.

Two parameters, total cover forest and total coniferous forest (Tab. 6), didn't show significant differences between nest circles and random circles: this result also incorporates the vegetation formations that were pooled in our analysis to define broadleaf forest (twelve categories from the vegetation map) and coniferous forest (three categories from the vegetation map). The significance (close to the minimum level $\mathrm{P}<0.05$ ) of the parameter total broadleaf forest refers firstly to the ordinal value 
Tab. 8 - Mean Diameter at Breast Height (DBH) of the nest tree and mean nests height in our area in comparison with available bibliography. * Mean nest height for broadleaf trees.

\begin{tabular}{|c|l|c|l|}
\hline Mean DBH $(\mathbf{c m})$ & Author & Mean nest height $(\mathbf{m})$ & Author \\
\hline 40 & Bocca 2007 & 6.9 & Bocca \& Falcone, 1999 \\
\hline 50.2 & Campodron et al., 2008 & 7.5 & Ceccarelli et al., 2008 \\
\hline 50.9 & Pirovano 2009 & 7.5 & Colpi et al., 2009 \\
\hline 51.2 & Kosinski et al., 2007 & 9.1 & Falcone 1998 \\
\hline 53 & Colpi et al., 2009 & 9.1 & Pirovano 2009 \\
\hline 55 & Ceccarelli et al., 2008 & 11.4 & Blume 1996 \\
\hline 55.2 & Henke 1996 & $11.9(10.8)^{*}$ & this paper \\
\hline 59.5 & This paper & 12.4 & Kosinski et al., 2007 \\
\hline
\end{tabular}

of the parameter (higher in nest circles than in random ones) and, again, incorporates all the broadleaf categories of the vegetation map: the species needs a minimum (threshold) amount of broadleaf cover as feeding area; on the contrary, the species avoids an excessive urban cover $(\mathrm{P}<0.0466)$. It's worth noting the significance $(\mathrm{P}<0.0155)$ of the parameter "number of dead plant (snag/log)": the deadwood represents an irreplaceable feeding substrate (Fig. 3) for the species and in all the territories we found clear evidence of feeding holes and signs in the rotten wood (stumps, snags and logs); in Switzerland the increase of the populations (period 1990-2008) of several forest species such as Black Woodpecker, Middle and Lesser Spotted Woodpeckers, Willow and Crested Tit, has been directly related (Mollet et al., 2009) to the increase of the quantity of deadwood, thanks to a "close-to-nature" approach to forest management. This species is increasingly adapting to the environmental mosaic of the central sec-

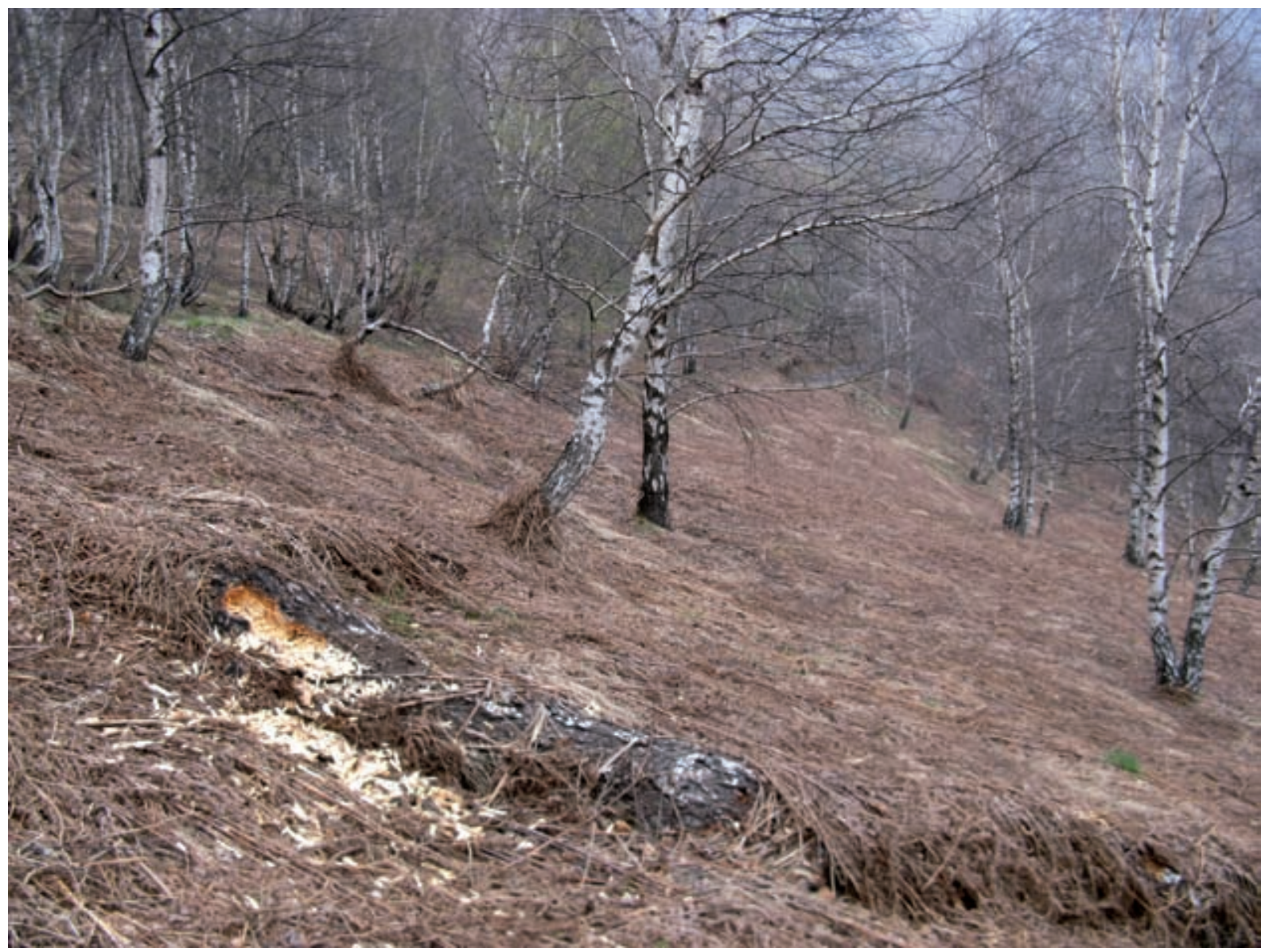

Fig. 3 - Feeding area in the mountain birch woodland of the SCI Val Veddasca: in foreground a wide feeding hole in a rotten log of birch, with wood chips scattered around. Photo by Fabio Saporetti. 
tor of the province, which comprises an higher level of urban cover than sector A and B; precisely in the area of territory n.9 (Fig. 4), in the years 2000/2001 we studied (Saporetti \& Guenzani, 2004) the whole bird community of a patch (15.9 ha) of unmanaged alluvial wood (AlnoPadion - Salicion albae formation): the species pool does not included the Black Woodpecker, although the mature wood already hosted a rich population of the commonest Picidae (Dendrocopos major, Dendrocopos minor, Picus viridis). In 2010, when we censused the successful breeding pair, the nest tree was only $160 \mathrm{~m}$ from the nearest

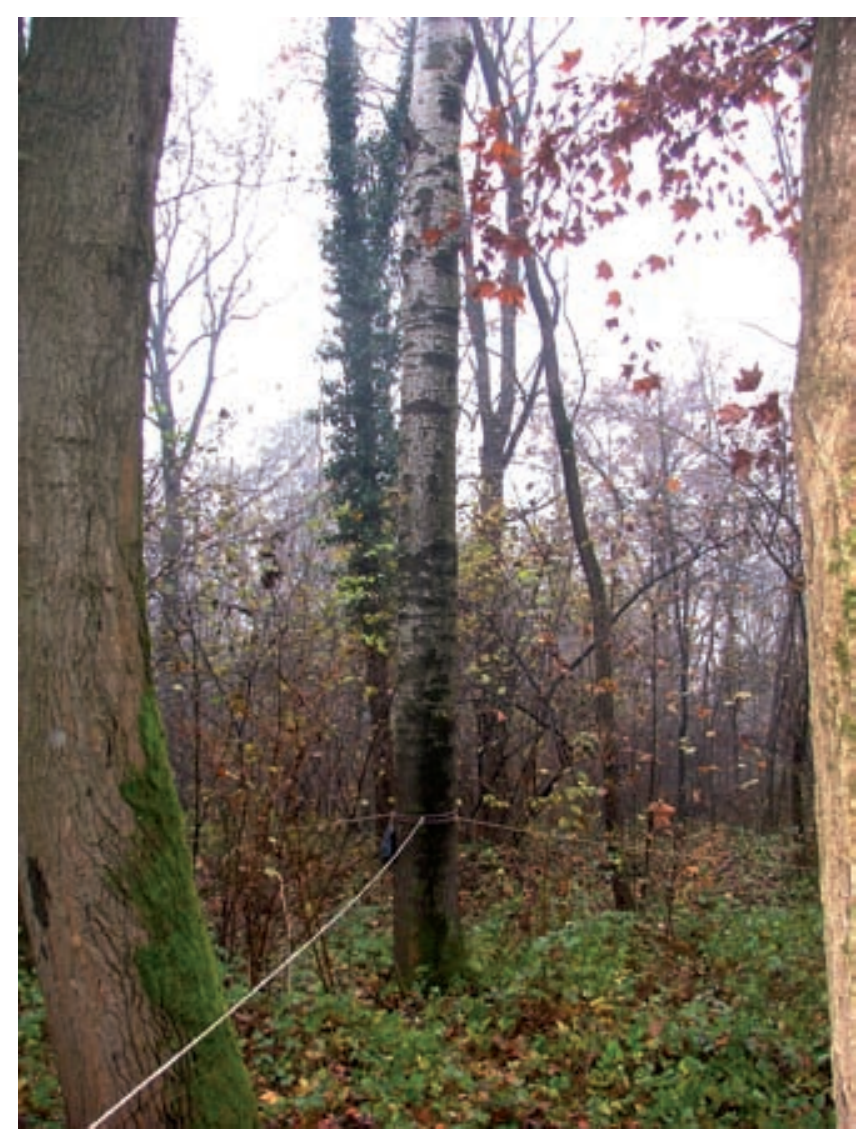

FIg. 4 - .Nest tree (Popolus alba) in territory n. 9 (C area), close to Lake Varese, at the altitude of $245 \mathrm{~m}$ a.s.l., the lowest one in which we found a breeding pair in the ash-alder forest. In the photograph are visible some of the ropes of $20 \mathrm{~m}$ used to delimitate the 0.12 ha circle, where we measured the forest parameters. Photo by Lorenzo Colombo. paved road (a busy provincial one in Varese municipality) and from $170 \mathrm{~m}$ from the nearest urban area. In the same sector another successful pair (territory n.10, $2.3 \mathrm{~km} \mathrm{~S} / \mathrm{E}$ from n. 9) in 2011/12, was at only 120 meters from the same busy paved provincial road and from $340 \mathrm{~m}$ from a shopping centre. The territories of the Black Woodpeckers were dispersed in quite different vegetation categories (Pignatti, 2003; Tab. 9), suggesting an increasing adaptability of the species: from the customary Scots pine and Beech forest, to the Ash-Alder forest of the lowest altitudinal range (around $250 \mathrm{~m}$ a.s.1.), further comprising cultivated formation of Quercus rubra (territory n. 6) and degraded wood with Robinia pseudacacia (territory n. 2). These environmental factors clearly can't indicate the Black Woodpecker as a habitat specialist, and his flexibility in term of ecological requirements explains the spreading of the species from the original Alpine forest to the Pre-Alps and lowland plain following maturing forests with increasing dead-wood resources, diffusion of protected areas, and better protection of the species.

The distribution of Black Woodpecker in Varese province, from the northern mountain area, now includes all the central sector, further spreading on the east side in the southern lowland sector, following the landscape corridor adjacent to the Lake Maggiore and, further south, to the Ticino river (Casale et al., 2014). A recent analysis (Brambilla \& Saporetti, 2014) of suitable nesting habitat, modeling with MaxEnt the distribution at $1 \times 1 \mathrm{~km}$ scale, confirms a potential distribution throughout most of the provincial territory, with the exception of the southern and almost uninterrupted urbanized area, close to the Milan province.

\section{Acknowledgements}

We are very grateful to the members of our group that greatly supported our field work: Roberto Aletti, Sergio Baratelli, Rino Carraro, Lorenzo Colombo, Alessandro Madella, Mirko Tomasi, Andrea Vidolini. Many individuals helped with useful informations: Piero Bonvicini, Mattia Brambilla, Paola Bressan, Enrico Cairo, Monica Carabella, Paolo Casali, Piero Castelli, Gianluca Danini, Roberto Facoetti, Enrico Giussani, Alison Parnell, Colin Parnell, Federico Pianezza, Laura Rinetti, Chiara Scandolara. Mattia Brambilla offered helpful comments and suggestions. We are grateful to Giuseppe Bogliani and an anonymous reviewer for useful comments, improving an earlier version of the manuscript. Our thanks to Colin Parnell for revising the English text.

Tab. 9 - Vegetation categories relating to the territories of Black Woodpeckers.

\begin{tabular}{|l|c|}
\hline Vegetation categories and category number according to Pignatti 2003 & Territory number \\
\hline Scots pine with Quercus robur and Molinia - 4 & 1 \\
\hline Spontaneous formation of Robinia pseudacacia - 14 & 2 \\
\hline Acidophilous and thermophilous beech forest - 8 & $3-4-7-8$ \\
\hline Ash-alder forest - 13 & $5-9-10$ \\
\hline Cultivated deciduous broad-leaved forest - 19 & 6 \\
\hline
\end{tabular}




\section{REFERENCES}

Aimassi G. \& Reteuna D., 2007 - Uccelli nidificanti in Piemonte e Valle d'Aosta. Aggiornamento della distribuzione di 120 specie. Memorie dell'A.N.P., 7: 1-120.

Bianchi E., Martire L. \& Bianchi A., 1973 - Gli uccelli della provincia di Varese (Lombardia). Estratto da Rivista Italiana di Ornitologia.

Blume D., 1996 - Schwarzspecht, Grauspecht, Grünspecht. Die Neue Brehm-Bücherei Bd. 300. Westarp Wissenschaften, Magdeburg.

Bocca M., 2007 - Il Picchio nero nel Parco Naturale Monte Avic. Parco Naturale Monte Avic, Champdepraz.

Bocca M. \& Falcone U.G., 1999 - Caratteristiche dei siti riproduttivi del Picchio nero Dryocopus martius in una valle delle Alpi Graie (Parco Naturale del Mont Avic, Valle d'Aosta). Atti del X Convegno Italiano di Ornitologia, Caorle: 23-26 settembre 1999. Avocetta 23: 112.

Bocca M., Rolando A. \& Carisio L., 2007 - Habitat use, home range and census techniques in the Black Woodpecker Dryocopus martius in the Alps. Ardea: 95 (1): 17-29.

Brambilla M. \& Saporetti F., 2014 - Modelling distribution of habitats required for different uses by the same species: implications for conservation at the regional scale. Biological Conservation, 174: 39-46.

Brichetti P. \& Fasola M., 1990 - Atlante degli uccelli nidificanti in Lombardia 1983-1987. Editoriale Ramperto, Brescia.

Brichetti P. \& Fracasso G., 2007 - Ornitologia Italiana. Vol. 4. Apodidae-Prunellidae. Oasi Alberto Perdisa Editore, Bologna.

Camprodon J., Salvanyà J. \& Soler-Zurita J., 2008 - The abundance and suitability of tree cavities and their impact on hole nesting birds populations in beech forests of NE Iberian peninsula. Acta Ornithologica, 43: 17-31.

Casale F., Sala D. \& Bellani A. (a cura di), 2014 - Il patrimonio faunistico del Parco del Ticino negli anni 2000. Parco Lombardo della Valle del Ticino e Fondazione Lombardia per 1'Ambiente. <http://www.flanet.org/ sites/default/files/pubb/Patrimonio_faunistico_Parco Ticino lr.pdf $>$

Ceccarelli P.P., Agostani N., Milandri M. \& Bonora M., 2008 - Il Picchio nero Dryocopus martius (Linnaeus 1758) nel Parco delle Foreste Casentinesi (Aves, Piciformes, Picidae). Quaderno di studi e notizie di storia naturale della Romagna, 27: 143-154.

Colpi C., Varaschin M., Zenatello M. \& Luise R., 2009 Selvicoltura ed avifauna sensibile. Il caso del Picchio nero (Dryocopus martius) nel Parco Nazionale delle Dolomiti Bellunesi. Atti del Terzo Congresso Nazionale di Selvicoltura. Taormina (ME), 16-19 ottobre 2008. Accademia Italiana di Scienze Forestali, Firenze: 163-168.

Cramp S. (ed.) 1985 - Handbook of the birds of Europe, the Middle East and North Africa. The Birds of the Western Palearctic, Vol. 4. Oxford University Press, Oxford.
Cuisin M., 1968 - Essai d'une monographie du pic noir. Oiseau et la Revue Française d'ornithologie, 38: 2052; 103-126; 209-224.

Falcone U.G., 1998 - Ambienti di nidificazione del Picchio nero Dryocopus martius (Linnaeus 1758) nel Parco del Mont Avic (Valle d'Aosta). Corso di laurea in scienze biologiche, anno Accademico 1997/1998. Università degli Studi di Torino.

Gagliardi A., Guenzani W., Preatoni D.G., Saporetti F. \& Tosi G. (a cura di), 2007 - Atlante Ornitologico Georeferenziato della Provincia di Varese. Uccelli Nidificanti 2003-2005. Provincia di Varese; Civico Museo Insubrico di Storia Naturale di Induno Olona; Università degli Studi dell'Insubria, sede di Varese.

Gorman G., 2011 - The Black Woodpecker. A monograph on Dryocopus martius. Lynx Edicions, Barcelona.

Guenzani W. \& Saporetti F., 1987 - Atlante degli uccelli nidificanti in provincia di Varese 1983-1987. Edizioni Lativa, Varese.

Gustin M., Brambilla M. \& Celada C. (a cura di), 2009 Valutazione dello Stato di Conservazione dell'avifauna italiana. Rapporto Tecnico Finale. Ministero dell'Ambiente e della Tutela del Territorio e del Mare, Lega Italiana Protezione Uccelli (LIPU).

Henke D., 1996 - Durchführung und Bewertung einer Kartierung zum Vorkommen Hügelbauender Waldameisen und zur Brutbaumverteilung bezüglich der Bunt- und Schwarzspechtpopulation auf Revierebene. Diplomarbeit, FH Eberswalde, Unveröff.: $68 \mathrm{~S}$.

Kosinski Z. \& Kempa M., 2007 - Density, distribution and nest-sites of Woodpeckers Picidae, in a managed forest of western Poland. Polish Journal of Ecology, 55 (3): 519-533.

Kunzmann G., Meyer W., Meyer B. \& Christensen H., 2008 - Über die postembryonale Entwicklung der Körpemasse beim Schwarzspecht Dryocopus m. martius. Anzeiger des Vereins Thüringer Ornithologen, 6: 55-66.

Lang E. \& Rost R., 1990 - Brutaktivität, Bruterfolg und Schutz des Schwarzspechtes Dryocopus martius. Vogelwelt, 111: 28-39.

Lange U., 1996 - Brutphänologie, Bruterfolg und Geschlechterverhältnis der Nestlinge beim Scwarzspecht Dryocopus martius im Ilm-Kreis (Thüringen). Vogelwelt, 117: 47-56.

Meyer W. \& Meyer B., 2004 - Beobachtungen zur Reproduktion der Schwarzspechtes Dryocopus martius in Wirtschaftwäldern Ostthüringens. Anzeiger des Vereins Thüringer Ornithologen, 5: 49-56.

Mikunsinski G., Gromadzki M. \& Chilarecki P., 2001 Woodpeckers as indicators of forest bird diversity. Conservation Biology, 15: 208-217.

Mollet P., Zbinden N. \& Schmid H., 2009 - Steigende Bestandszahlen bei Spechten und anderen Vogelarten dank Zunahme von Totholz? Schweizerische Zeitschrift für Forstwesen, 160 (11): 334-340.

Parnell C., Parnell A. \& Guenzani W., 1994 - Prima nidificazione di Picchio nero, Dryocopus martius, in provincia di Varese. Rivista Italiana di Ornitologia, 64: 80-81. 
Pasinelli G., 2006 - Population biology of European woodpeckers species: a review. Annales Zoologici Fennici, 43: 96-111.

Pignatti S., 2003 - Guida alla classificazione della vegetazione forestale. Inventario Nazionale delle Foreste e dei Serbatoi Forestali di Carbonio. Istituto Sperimentale per l'Assestamento Forestale e per l'Alpicoltura.

Pirovano A., 2009 - Il picchio nero (Dryocopus martius). Un "falegname" per la conservazione della biodiversità nelle foreste alpine. Suppl. Vol. 20-2009 de "Il naturalista Valtellinese". Atti del Museo civico di Storia naturale di Morbegno.

Pynnönen A., 1939 - Beiträge zur Kenntnis der Biologie finnischer Spechte I. Annales zoologici Societatis zoologicae-botanicae Fennicae Vanamo, 7 (2): 1-166.

Rolstad J., Majewski P. \& Rolstad E., 1998 - Black Woodpecker use of habitats and feeding substrates in a managed Scandinavian forest. Journal of Wildlife Management, 62 (1): 11-23.

Rolstad J., Rolstad E. \& Saeteren O., 2000 - Black Woodpecker nest sites: characteristics, selection, and reproductive success. Journal of Wildlife Management, 64 (4): 1053-1066.

Rudat V., Meyer W., Kuhlke D. \& Keutsch S., 1981 Bruterfolg, Jungenzahl und Geschlechterverhältnis der Nestlinge beim Schwarzspecht (Dryocopus marti$u s$ ) in Thüringen. Ornithologische Jahresberichte des Museum Heineanum, 5-6: 61-64.

Saporetti F. \& Guenzani W., 2004 - La comunità ornitica delle formazioni forestali ad Alno-Ulmion e Salicion albae: analisi di alcune aree-campione in Provincia di Varese (Lombardia). Bollettino Società Ticinese di Scienze Naturali, 92 (1-2): 109-118.

Saporetti F. \& Pianezza F., 2010 - La pianificazione forestale e la conservazione di specie di interesse comunitario. Relazione Tecnica non Pubblicata. Comunità Montana Valli del Verbano.

Tosi G. \& Zilio A. (eds.), 2002 - Conoscenze delle risorse ambientali della Provincia di Varese-Progetto SIT-Fauna. Provincia di Varese, Settore politiche per l'Agricoltura e Gestione Faunistica.

Utmar P. \& Padovan P., 2005 - Il Picchio nero, Dryocopus martius, nidificante in pianura nel Friuli Venezia Giulia. Rivista Italiana di Ornitologia, 75 (1): 62-64. 